\title{
GOING GLOBAL - ACTING LOCAL: MARKETING STRATEGY OF SIEMENS IN SERBIA
}

\author{
Aleksandra Stojiljković1, Slađana Đurić2 \\ ${ }^{1,2}$ Faculty of Economics in Subotica, University of Novi Sad; Republic of Serbia \\ aleksandra.stojilikovic@gmail.com; dalisla@mts.rs
}

\section{Original Scientific Paper doi:10.5937/jouproman6-18693}

\begin{abstract}
When a company has been operating in the world for 170 years, and for 125 years in one specific country, it more than surely deserves to have its business and marketing strategy considered. There are not so many companies that have achieved this and not so many companies can serve as an example of how a global company can be domestic. This is the case with Siemens in the world and Siemens in Serbia, and there is probably no company which has influenced the industrial and economic development of Serbia in such a powerful way as Siemens. This is a sufficient reason for studying the marketing strategy of Siemens, with the focus of this paper on studying the business and marketing strategy of Siemens in Serbia, in order to identify the marketing strategy that has brought this company to global success and which can be used by other companies in their presentation in the global market.
\end{abstract}

Key words: Siemens, marketing strategy of Siemens, marketing strategy of Siemens in Serbia

\section{Introduction}

Since Werner von Siemens invented the first pointer telegraph and together with Johann Georg Halske founded the company "Telegraphen-Bauanstalt von Siemens \& Halske" in Berlin with 10 employees (1847). What followed was opening of London office "Siemens, Halske \& Co." headed by William Siemens (1850), the office in St. Petersburg (1855), Brussels (1871), Paris and The Hague (1878), Vienna and Warsaw (1879), Stockholm and Turin (1880), New York (1886), Tokyo (1887), Rio de Janeiro (1888), Budapest (1890) and Chicago (1892). From establishing the Russian state telegraph network (1853) to the Digital Hub in Singapore (2017), from discovery of the dynamo machine by Werner von Siemens (1866) to MindSphere (2016), through sales difficulties during World War I and World War II to the overcoming of the crises, from employees' first shares in company results (1858) to present Business to Society concept, Siemens has become during this 170-year-long period a worldwide global company, with around 377,000 employees in more than 200 countries/regions (Wegener and Karczewski, 2017). Today, according to Siemens - Global (2018) "Siemens is a global leader in electrification, automation and digitization, and one of the world's largest manufacturers of energy efficient resource saving technologies and a leading provider of power generation and transmission systems, as well as medical diagnosis and infrastructure and industrial solutions in which the company has a leading role".

In its global business and marketing strategy, the company applies the principle of local operating by opening its own companies in foreign countries, which requires large investments in the research and development of each individual market, the costs of adapting to domestic economic, cultural and political conditions, but it also brings great benefits. 
In its 170-year-long history, Siemens has been operating for 125 years in Serbia. A few companies in the world have such a long tradition of doing business in a country and business in global. Such a long history and successful operation of Siemens in the global market, as well as its long tradition in Serbia market and the importance of company for the economy development in Serbia, is certainly a sufficient reason to study its business and marketing strategy. There is not much literature on this subject, so the aim of this paper is, through the study of the marketing strategy of one such successful company in global market as well as in Serbia market, to contribute to the study of Siemens marketing strategy, as well as to pay homage to importance of Siemens in Serbia.

The first part of this paper is focused on the study of key elements of the Marketing Strategy of Siemens, the main competitive advantages and the analysis of competition in the global market, while the second part is focused on the study of Siemens marketing practice in Serbia. The last part relates to the conclusions we have reached in this analysis - what the elements of the marketing strategies of successful global companies such as Siemens are, which can serve as a guide to other companies operating under the conditions of global market competition.

\section{Marketing Strategy of Siemens}

The focus of Siemens marketing strategy is on careful segmentation and targeting foreign markets and on long-term positioning in them through the development of core competitive advantages.

\subsection{The core elements of Marketing Strategy of Siemens}

Segmentation, targeting, positioning (STP): The STP model according to
Hanlon (2018) plays an important role in creating marketing communications plans that allow marketers to prioritize propositions, then develop and provide personalized and relevant messages to different segments of the audience. STP is focused on commercial efficiency, selecting the most important business segments, and then developing a marketing and product positioning strategy for each segment.

Rakita (2012) explains that the significance of the segmentation of the market in international marketing, as a strategic approach to international market targeting, except in respect of more adequate selection of foreign markets, has a great importance in the process of planning, organizing and controlling international marketing activities, given its preventive character, which enables successful international market selection. In international business environment, the significance of segmentation is particularly increased due to the greater heterogeneity of the market in demographic and cultural terms, as well as in the socio-political and economic-developmental terms (Jović, 2002; Rakita, 2012).

According to Bhasin (2018) "Siemens uses geographic and demographic segmentation strategies for the products for B2B businesses and demographic and psychographic segmentation strategies for the products and services intended for retail customers and differentiating targeting strategy to target MNC's and government organizations to sell its products bundled with other offerings. The company has positioned itself as a brand having a global presence and as a pioneer in electrical engineering and automation processes, and uses customer benefit positioning strategy to achieve that". 
Competitive advantage: What features distinguished Siemens from other companies and enabled it to have a 170year-long history of successful business?

Research and development $(R \& D)$ : This is a key component of the Siemens marketing strategy which implies constant investments in the development of innovative and sustainable solutions for the customers, in accordance with the company's strategy and safeguarding of competitive advantages. This is confirmed by Annual Financial Report of the company (AFR, 2017) according to which "in fiscal 2017 company reported research and development expenses of $€ 5.2$ billion, compared to $€ 4.7$ billion in fiscal 2016 . The resulting $R \& D$ intensity, defined as the ratio of $R \& D$ expenses and revenue, was $6.2 \%$, thus above the R\&D intensity of $5.9 \%$ in fiscal 2016. Additions to capitalized development expenses amounted to $€ 0.4$ billion in fiscal 2017, compared to $€ 0.3$ billion in fiscal 2016. As of September 30, 2017, Siemens held approximately 63,000 granted patents worldwide in its continuing operations. As of September 30, 2016, it held approximately 59,800 granted patents. On average, company had $37,800 \quad \mathrm{R} \& \mathrm{D}$ employees in fiscal 2017".

Innovativeness: From the beginning, Siemens was defined by its innovativeness. Its innovativeness started with the pointer telegraph, then with the dynamo machine and, as can be seen today in innovations like MindSphere, an operating system for the Internet of Things (ToI). Over time, key creators of the company history combined scientific curiosity with entrepreneurial action to make Siemens the leading standard-setting company and master of the entire value chain of electrification in the way that few competitors can do it (Wegener and Karczewski, 2017).
Internationality: Operating in Russia was just the beginning. It soon became clear that the company had an international ambitions. But a lot of effort was required to establish the company as a local partner and a member of local society. To achieve this, it was not enough to simply speak the local language, it meant understanding attitudes and local customs, and acknowledging them, and applying them wherever they are consistent with the values of the company as a whole (Wegener and Karczewski, 2017). The company is viewed not as a German company, but as a local company in each country. This is what makes Siemens truly international.

Focus on quality and customers: This quality also emerged early in the company's history. According to Wegener and Karczewski (2017) this quality and customer focus is visible, for example, in Siemens' founding of a digital hub in Singapore and its collaboration with customers, partners and representatives of civil society there, to address the major questions of the future facing the citystate.

Proven itself in crises and ability to change: Crises are part of company's history, but it has always found ways to overcome them, and come out stronger each time, improving its main advantages.

Responsible action: Werner von Siemens incorporated this value into the company's strategy from the very beginning. He thought that responsibility requires all employees to act as though the company is their own, and creates an "ownership culture" that is brought to life every day.

Competitive analysis: A global company has many competitors, but in this paper we will highlight some of the main competitors in several of the company's major business sectors. 
Amor, Valls, Casserras and Cortegiani (2013) point out that one of the company's main competitors certainly is General Electric Co. (US), then Bombardier Inc. (Canada) and Alstom SA. (France) in the rail manufacturing sector, $\mathrm{ABB}$ Ldt. in energy sector, and Philips Electronics N.V. (Netherlands) in healthcare sector.

\subsection{Marketing mix of Siemens}

The Marketing mix as a set of controllable variables serves to achieve a higher level of customer satisfaction and, at the same time, achieves its objectives (Kotler and Keller, 2017).

Product: Siemens focuses on electrification, automation and digitalization. It operates in ten divisions: Building Technologies, Drive Technology, Energy, Healthcare, Industrial Automation, Mobility, Financing, Consumer Products, Services and Software. The Building technologies division provide products, services and solutions in its marketing mix that optimizes the performance, energy costs and infrastructure of buildings (Mba skool, 2018). The Energy management division provides cutting-edge products and services covering the entire energy value chain like turbines and generators to virtual power plants or intelligent grid management and innovative storage solutions. Healthcare is separately managed business, with powerful mix of unique products and services like Medical Imaging, Ultrasound or Healthcare IT. Within the hardware and software portfolio of the company MindSphere, cloud-based, open IoT operating system that connects products, plants, systems, and machines has already been mentioned, enabling to harness data generated by the Internet of Things (IoT) with advanced analytics (Siemens - Global, 2018).
Price: Siemens is present in different sectors, so the company's pricing policy is different for each of them. According to Annual Financial Report of the company for 2017 (AFR, 2017), "Power and Gas businesses gives Siemens a profit margin of $11-15 \%$, Energy Management 7 $10 \%$, Building Technologies $8-11 \%$, Mobility $6-9 \%$, Digital Factory $14-$ $20 \%$, Process Industries and Drives 8 $12 \%$, Healthineers $15-19 \%$ and Siemens Gamesa Renewable Energy gives Siemens a profit margin of $5-8 \%$. These percentages show that the company was profitable in fiscal 2017 thanks to the policy of lower prices achieved by a mix of lowering production and installation costs, and positive effects of project execution and completion. Investments in $\mathrm{R} \& \mathrm{D}$ are still high, as can be seen in the previous section".

Place: Siemens is one of the leading global business leaders with business units in more than 200 countries and with over 370,000 employees. Siemens operates all over the world on all continents and in almost every country like Austria, Australia, Brazil, China (also see Ahsan, Qazi, Shahabuddin and Khan, 2014), Chile, Denmark, Egypt, India, Japan, Serbia etc. Table 1. shows the company's presence in particular countries according to the revenue and the number of employees in fiscal 2017.

Promotion: Siemens has a very intensive approach to its marketing mix strategy to reach the desired audience. It uses both traditional and modern marketing tools, such as TV ads, online videos and print ads and social media as well (Facebook, Twitter etc.) to promote its campaigns. Some of the famous Siemens campaigns are: "Answers", "Face the nation", "Good Morning America", "Meet the press" and "Ingenuity for life" (Mba skool, 2018). 
Table 1. Global presence in fiscal 2017

\begin{tabular}{|c|c|c|}
\hline Country & & $\begin{array}{l}\text { Share of total } \\
\text { Worldwide }\end{array}$ \\
\hline \multicolumn{3}{|l|}{ Americas } \\
\hline Revenue $^{1}$ & $€ 23.5$ billion & $28 \%$ \\
\hline Employees $^{2}$ & 76,000 & $20 \%$ \\
\hline \multicolumn{3}{|l|}{ Germany } \\
\hline Revenue $^{1}$ & $€ 11.1$ billion & $13 \%$ \\
\hline Employees ${ }^{2}$ & 118,000 & $31 \%$ \\
\hline \multirow{2}{*}{\multicolumn{3}{|c|}{$\begin{array}{l}\text { Europe (excluding Germany), } \\
\text { CIS }^{3} \text {, Africa, Middle East }\end{array}$}} \\
\hline & & \\
\hline Revenue $^{1}$ & $€ 32.2$ billion & $39 \%$ \\
\hline Employees $^{2}$ & 113,000 & $30 \%$ \\
\hline \multicolumn{3}{|l|}{ Asia, Australia } \\
\hline Revenue $^{1}$ & $€ 16.2$ billion & $19 \%$ \\
\hline Employees $^{2}$ & 70,000 & $19 \%$ \\
\hline \multicolumn{3}{|c|}{$\begin{array}{l}\text { 1 As reported in FY 2017; by customer location } \\
2 \text { As of September } 30,2017 \text {. With beginning of FY } 2018 \text { part time employees are included to the full extent. Prioryear information is } \\
\text { presented on a comparable basis } \\
3 \text { Commonwealth of Independent States } \\
\text { All figures refer to continuing operations. }\end{array}$} \\
\hline
\end{tabular}

Source: Siemens-Global, 2018

\section{Marketing Strategy of Siemens in Serbia}

Siemens has been operating in Serbia for 125 years since 1887 , but it was actually present long before. The first product of Siemens \& Halske, which appeared in Serbia, was the arc lamp, which was used for the first time to illuminate the National Theater in Belgrade in 1882, and the second one was the first telephone in Serbia (1883). According to Marković, Antić and Šarenac (2012) from the first arc lamp in Belgrade during 1881-1882, Siemens began to play a key role in the electrification of Serbia, through the first electric power station in Dorćol in Belgrade (1893), and then the first Serbian hydroelectric power station "Under the city" near Užice (1900) which is also the first electric power station built according to Tesla's principles of polyphase alternating current system in Serbia and the other in the world, after Niagara in America. Then, hydroelectric power plants were built near Leskovac (1903), Niš (1908), Ivanjica (1911) and Zaječar (1909), with Siemens equipment installed in each of them. 1923 Siemens delivers state-of-the-art electronic trams for the needs of Belgrade's city transport, and the first automatic telephone exchange system by Siemens started operating in Novi Sad (1927) and then in Belgrade (1931). In 1941, " Srpski Siemens Elektrik a.d." was founded, and in 1945 "Genex" company started representing Siemens, and in 1960 Siemens started production and technological cooperation with EI Niš, after which the Factory of High Frequency Devices, together with Siemens and Genex, founded joint venture company under the name "EI VF-TEL" in 1990 (Marković et al., 2012).

According to Siemens-Serbia (2018) in 1996, April $8^{\text {th }}$, the local company Siemens d.o.o. Belgrade was founded, which currently employs about 1750 employees engaged in all areas in which the parent company is active, and in 2005 Siemens bought the factory Loher Elektro Subotica, which produces generators for windmills, in which about 1600 of total employees work in. 
Operating through a local company is one of Siemens's key approaches in its global marketing strategy. Local company operates in the field of electrification, automation and digitization, which are also the areas of Siemens's long-term progress, and in order to fully take advantage of the market potential in these areas, Siemens d.o.o. Belgrade is grouped into nine divisions, where the healthcare division is additionally allocated as part of the business that is managed separately (Siemens-Serbia, 2018). These divisions produce a wide range of products and solutions for the successful handling of fossil fuel power plants, the use of renewable energy sources, economical, reliable and intelligent transmission and distribution of electricity, efficient and integrated transportation of people and goods by rail and road or supply of modern medical and laboratory infrastructure.

These products are distributed to public and private companies, such as utility services or, for example, public or independent electricity producers, engineering, procurement and construction companies (EPC) or industrial customers, for example, oil industry and gas industry, all over Serbia, but also in the region and beyond (Siemens-Serbia, 2018). According to Marković et al. (2012) the company has developed very successful cooperation with some of the largest Siemens customers in Serbia, such as EPS, EMS, NIS-Gazprom Neft, FIAT, Kolubara and many others, through partnerships and joint ventures.

As an important part of this marketing mix within Siemens's marketing strategy in Serbia, throughout its 125-year-long history in this market, when promoting its own products or those belonging to its partners (such as Telefunken), Siemens used a large number of advertisements published in daily or monthly press and professional journals stated until 1941. The central part of almost every advertisement in that time was dedicated to the drawing or photographs of the Siemens product with the description of the features of Siemens equipment, and the accompanying graphics were paid special attention. According to Marković et al. (2012) part of the material distributed in Serbia was printed in Cyrillic according to local market affinities. In addition to the telephone, Siemens' orientation to the radio, in the sense of production and marketing, is very interesting, considering that the radio at that time was still a luxury product and considered as a privilege, but it was especially interesting for the company, both from the production and marketing perspectives, because the devise was portable and it could be used out of home.

Experiments were carried out with the radio set in the car, which was also a challenge in the sense of production and marketing at that time. Siemens introduced their radio devices to potential customers and partners at fairs and radio shows, for example, Belgrade radio show in 1936. In addition, Siemens also participated in broader marketing campaigns aimed at promoting the use of electricity in households, with the help of Bipel, ie. the propaganda bureau for the use of electricity in Serbia (1937), and what is most interesting, the first neon sign in Belgrade was actually the Siemens commercial for Telefunken (Marković et al., 2012).

Since that time, technology has progressed drastically, but the needs of marketing to adapt to the economic, social, cultural and political conditions of one country have remained the same.

The marketing strategy of Siemens in Serbia has been affected by numerous turbulent circumstances. The company has had to leave the market several times due to political circumstances, but for example, during the economic sanctions in Serbia, Siemens played an important role in providing assistance. 
There were other economic and sociocultural difficulties that the company successfully overcame, which is confirmed by 125 years of its successful business in Serbia.

Since the beginning, the company has had a long-term orientation towards the Serbian market, which shows numerous innovations and investments, where the company has never given up its core elements of marketing strategy investments in research and development, investments in education through student support programs, sponsorships in the field of science, culture and sports, investments in people and the environment, through socially responsible behavior. According to Marković et al. (2012) through Siemens Educational Program Siemens Generation 21 companies have been helping students and professors in technical sciences to gain the latest knowledge, and encourage young people to become interested in technical professions. Within this program, Siemens has organized a competition for elementary and secondary school students called Create the Future. Within the framework of environmental protection, Siemens Serbia launched the internal project "Siemens Green Week", as well as the project "Energy Efficiency and Environmental Protection" and many others projects aimed at raising the awareness of employees and all others of environmental protection.

Siemens has become an integral part of the domestic economy that provides a constant contribution to economic progress in all regions and all sectors of the economy as a promoter of significant cultural, scientific, artistic and sports events, which further confirms that the company wants to remain permanently in this region.

The history of Siemens in Serbia represents a significant part of the history of Serbian economic development, and company that has been present in Serbia for 125 years is an important part of development of Serbia.

\section{Conclusion}

In its global marketing strategy Siemens applies a strategy of careful market selection and diversification based on key competitive advantages that involve constant innovation that has been its key aspiration since the beginning. Research and development require the largest investments of the company, as well as the internationalization, which means being present in every country. The company's priority in production and marketing is also providing of high quality products and services, as well as customer, employees and the environment care, and prove itself in crisis circumstances. This marketing strategy, in which one of the main business philosophy of Siemens - to be a good citizen of the country in which you work (which was the case with Siemens in Serbia) has brought the company to global success. It could serve as an example for other companies in their attempt to succeed in the global market - how to think global, and act local.

\section{Literature:}

1. Ahsan. L., Qazi. B., Shahabuddin. S., Khan. M. A. (2014). Marketing Strategy of Siemens Engineering Company in Chinese Business Environment. Research Journal of Engineering Sciences, 3(9), 7-11.

2. Amor. P., Valls. C., Casserras. G., Cortegiani. A. (2013). Qualitative and Quantitative analysis of Siemens AG. Barcelona: Universitat de Barcelona.

3. Bhasin, H. (2018). Marketing Strategy of Siemens - Siemens Marketing Strategy. Retrieved August 2018, from Marketing91: https://www.marketing91.com/marketingstrategy-siemens/

4. Hanlon, A. (2018). The Segmentation, Targeting and Positioning model. Retrieved August 2018, from Smart Insights: https://www.smartinsights.com/digitalmarketing-strategy/customer-segmentation- 
(JPMNT) Journal of Process Management - New Technologies, International

Vol. 6, No 4, 2018.

targeting/segmentation-targeting-and-

positioning/

5. Jović, M. (2002). Međunarodni marketing. Beograd: Institut ekonomskih nauka.

6. Kotler, P., Keller. L. K., (2017). Marketing menadžment, 15 izdanje. Beograd: DATA STATUS.

7. Marković. J. P., Antić. Č., Šarenac. D. (2012). Korak ispred vremena 125 godina Simensa u Srbiji. Beograd: Siemens d.o.o. Beograd, Institut za savremenu istoriju.

8. Mba skool. (2018). Siemens Marketing Mix. Retrieved August 2018, from mba skool: https://www.mbaskool.com/marketingmix/products/17112-siemens.html

9. Rakita, B. (2012). Međunarodni marketing. Beograd: Centar za izdavačku delatnost Ekonomskog fakulteta u Beogradu.

10. Siemens - Global. (2018). About Siemens. Retrieved August 2018, from Siemens Global:

https://www.siemens.com/global/en/home/co mpany/about.html

11. Siemens - Global. (2018). Annual Report 2017. Retrieved August 2018, from Siemens Global:

https://www.siemens.com/content/dam/webas setpool $/ \mathrm{mam} / \mathrm{tag}$-siemenscom/smdb/corporate-core/siemenscom/About_Siemens/siemens-ar2017.pdf

12. Siemens - Global. (2018). Products \& Services. Retrieved August 2018, from Siemens - Global:

https://www.siemens.com/global/en/home/pro ducts/software/mindsphere.html

13. Siemens - Serbia. (2018). About Siemens. Retrieved August 2018, from Siemens Serbia: http://www.siemens.rs/portal/onama/

14. Wegener, Ch., Karczewski, J. (2017). 1847 2017 - Shaping the future - Qualities that set Siemens apart - after 170 years. Retrieved August 2018, from Siemens - Global: https:/www.siemens.com/content/dam/webas setpool $/ \mathrm{mam} / \mathrm{tag}$-siemenscom/smdb/corporate-core/communicationand-gov-affairs/tl/HI/siemens-historicalinstitute/home/094-shi-siemens-at-170-yearsthe-siemens-narrative-2017-e.pdf 